\title{
A review of the Collyriinae (Hymenoptera: Ichneumonidae)
}

\author{
Mehmet Faruk Gürbüz \& Janko Kolarov
}

Gürbüz, F. M. \& Kolarov, J. 2006: A review of the Collyriinae (Hymenoptera: Ichneumonidae). - Entomol. Fennica 17: 118-122.

The species of the subfamily Collyriinae are reviewed. A new species from Turkey is described. A key for identification of the species is proposed.

M. Faruk, Faculty of Science and Art, Suleyman Demirel University, 32260 Isparta,Turkey; E-mail:mfg@fef.sdu.edu.tr

J. Kolarov, Faculty of Pedagogie, University of Plovdiv, 24 Tsar Assen Str., 4000 Plovdiv, Bulgaria; E-mail: j.kolarov@pu.acad.bg

Received 23 December 2004, accepted 27 July 2005

\section{Introduction}

The Collyriinae contains a single genus Collyria Schiødte of the Palearctic Region. It differs from the other Ichneumonidae subfamilies by the downward-curved ovipositor, tapered to a slender apex, with the apical half of the ventral margin having row of small weak teeth, and the absence of the dorsal subapical notch.

The female of Collyria coxator oviposits into the host egg and the parasitoid larva kills the fully-grown host larva in its cocoon (Salt 1931). The emergence is from the mature host larva.

The terminology used in this paper follows that of Gauld \& Bolton (1988).

\section{Collyria Schiødte, 1839}

Collyria Schiødte, 1839: Magazin de Zoologie (Insecta) 2(9):1-27.

(Pachymerus) Gravenhorst, 1829: Ichneumonologia Europaea 3:721.

Type species: Bassus calcitrator Gravenhorst, 1807.

The genus comprises eight Palearctic species (Yu \& Horstmann 1997). Collyria coxator (Villers), the most common species, was intro- duced in North America for biological control of Cephus pygmaeus L., which was accidentally introduced from Europe and became a pest of wheat (Filipy et al. 1985). A new species was found in the materials collected from Turkey and is described below.

\subsection{Collyria isparta sp. $n$.}

Material examined. Holotype 9 , Turkey, Isparta, Dere mahalesi, (37 $\left.40^{\prime} \mathrm{N}, 30^{\circ} 35^{\prime} \mathrm{E}\right), 1150 \mathrm{~m}$ a.s.1., 29.V.2004. The holotype is deposited at the collection of Plovdiv University, Faculty of Pedagogie, Plovdiv, Bulgaria. Paratypes: 1 त from the same locality, 29.V.2004, at the same

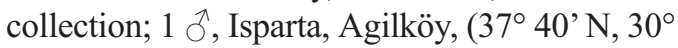
50' E) $1250 \mathrm{~m}$ a.s.1., 22.V.2004, deposited at the collection of Süleyman Demirel University, Biology Department, Isparta, Turkey.

Diagnosis. The new species is distinguished from all the other known species by its extraordinary scutellum; shorter antenna; almost rectangular connection of $2 \mathrm{~m}-\mathrm{cu}$ and cula veins in fore wings; shorter tibial spurs; and colouration of the body.

Description. Female: Front wing $5.4 \mathrm{~mm}$, body $8.5 \mathrm{~mm}$ long. Head swollen, weakly nar- 


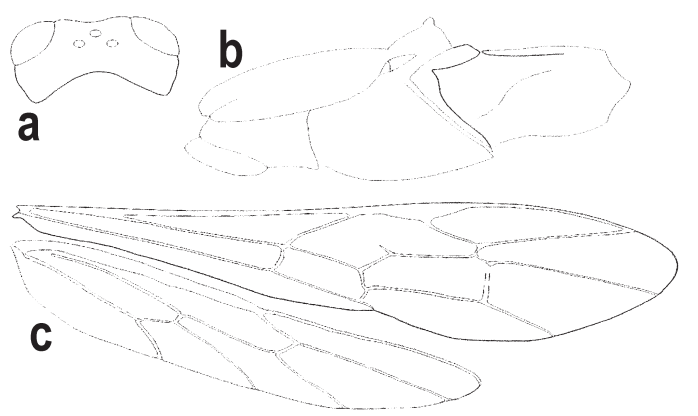

Fig. 1. Collyria isparta sp. n. - a. Head from above. b. Mesosoma, lateral view. - c. Fore- and hind-wings.

rowed behind the eyes (Fig. 1a). Flagellum with 19 flagellomeres, first flagellomere 3.5 times as long as wide, the flagellomere before the last one almost square. Eyes covered with short and sparse hairs. Face almost as high as wide, sparsely punctate and weakly convex in upper middle part, not separated from clypeus by a furrow. Gena 0.45 times as long as the basal width of mandible. Temple sparsely punctate, frons transversely striate.

Mesosoma 2.3 times as long as high. Notaulus not deep, but clearly visible. Upper frontolateral part of pronotum swollen. Subtegular ridge elongated and high. Scutellum pointed apically, with vertical hind side (Fig. 1b). Vein $2 \mathrm{~m}$-cu vertical to cula vein, with two bullae (Fig. 1c). Vein cula reaching $3 \mathrm{cu}$ vein a little below its middle. Vein $1 \mathrm{cu}-\mathrm{a}$ interstitial, $1 \mathrm{~m}$-cu vein with well developed ramellus. Vein cul in hind wing strongly reclivous, intercepted far above the middle. Hind coxa 2.9 times as long as wide, hind femur 3.8 times as long as wide. Hind tibia 10.3 times as long as wide apically, with apical spurs not longer than apical width of tibia. Length ratio of hind tarsomeres: $75: 50: 38: 20: 37$. Dorsal longitudinal carinae of propodeum almost parallel, reaching apical carina. Propodeal spiracle small, circular, nearer lateral than pleural carina. Mesosoma moderately coarsely and densely punctate, propodeum and metapleurum reticulate-punctate.

Metasoma slender, first segment 3.8 times as long as wide apically, its spiracle before the middle of the tergite. Second tergite 2.0 times as long as wide, third one 1.5 times as long as wide, transversely striate in basal half. The other tergites transverse. Ovipositor sheath 0.6 as long as hind tibia, and ovipositor compressed laterally. Black; two spots on inner eye orbits below antenna base, front and middle legs and base of hind femur red, hind tibia and tarsus brown, tergites I-III brownish black.

Male. Front wing $5.5 \mathrm{~mm}$, body $8.7 \mathrm{~mm}$ long. First flagellomere of the flagellum 3.7 times as long as wide. Ramellus longer. Fourth tergite as long as wide, fifth one square. Black; inner eye orbits widely yellow; metasoma entirely black, tergites IV-VII with yellow bands; front and middle femora darkened from behind.

Distribution. Turkey.

Etymology. The name of the species is from 'Isparta' province in Turkey, where specimens were collected.

\subsection{Collyria coxator (Villers, 1789)}

Ichneumon coxator Villers, 1789: Caroli Linnaei entomol., 3:193.

?Ichneumon falcata Geoffroy, 1785: Entomologia Parisiensis, Paris. 544.

?Ichneumon arcuata Olivier, 1792: Ichneumon. Encyc.meth., Hist. Natu. Insect. 7:133-224.

Bassus calcitrator Gravenhorst, 1807: Vergleichende Übersicht des Linneischen und einiger Neurern Zoologischen Systeme, nebst dem eingeschalteten Verzeichnisse der Zoologischen Sammlung des Verfasser und den Beschreibungen neuer Thierarten, die in derselben vorhanden sind. Göttingen: 476.

Pachymerus puncticeps Thomson, 1877: 27. Bidrag till kännedom om Sveriges Pimpler. Opuscula Entomologica, Lund 8:732-777.

Bassus calcitratrix Schulsz, 1906: Spolia Hymenopterologica. Paderborn (Junfermann): 356.

Description. The most common and widespread species in the region. Temple distinctly punctate, shining. Eye with sparse and short hairs. Body black, antenna ventrally yellowish, metasoma reddish with black base, sometimes also apically, more seldom metasoma almost dark, only tergites II-III brownish; hind tibia with yellowish base.

Host. Cephus pygmaeus L. and Trachelus tabidus F. (Cephidae).

Distribution. Western, Middle, South and 
South-Eastern Europe, Caucasus and Turkey (Kolarov 1997).

\subsection{Collyria distincta Izquierdo \& Rey de Castillo, 1985}

Collyria distincta Izquierdo \& Rey del Castillo, 1985: Eos 60: 55-65, male; 1986: 287-291, female.

Description. Flagellum with 19-20 segments. Vein $1 \mathrm{cu}-\mathrm{a}$ in fore wing antefurcal. Body reddishblack. Metasomal tergites with yellow bands apically, tergites II-III sometimes entirely yellow.

Distribution. Spain and North Africa (Izquierdo \& Rey del Catillo 1986).

\subsection{Collyria fuscipennis (Kriechbaumer,} 1894)

Pachymerus fuscipennis Kriechbaumer, 1894: Zool. Jahrb. Abt. Syst. 8(1895): 195-236.

Note. Only known to us by the description of the species and without seeing type specimens we cannot include it in the key.

Distribution. China (Kriechbaumer 1894).

\subsection{Collyria iberica Schmiedeknecht, 1908}

Collyria iberica Schmiedeknecht, 1908: Opusc. Ichn. 3: 1394.

Description. Flagellum with 21-23 flagellomeres. Temple finely punctate and striate. Face almost flat. Gena 0.5 times as long as basal width of mandible.

Distribution. Spain, Tunisia, Morroco and Algeria (Izquierdo \& Rey del Castillo 1985).

\subsection{Collyria nigricator Aubert, 1964}

Collyria nigricator Aubert, 1964: Bull. Soc. Ent. Mulh.: 35-40.

Description. Body shining. Flagellum with 20 flagellomeres. Gena almost absent. Body black; antenna ventrally, mandible, palpi, front and middle tibia, yellow.

Distribution. Syria (Aubert 1964).

\subsection{Collyria orientator Aubert, 1979}

Collyria orientator Aubert, 1979 (calcitrator ssp.): Bull. Soc. Ent. Mulh.: 17-22.

Description. Temple shining and finely punctate. Flagellum with 20-22 flagellomeres. Gena almost absent. Dorsal longitudinal carinae of propodeum not parallel. Body black; antenna ventrally, two spots on face, palpi and pterostigma, yellow; middle of metasoma reddishbrown.

Distribution. Palestine, Syria, Cyprus and Sicily (Izquierdo \& Rey del Castillo 1985).

\subsection{Collyria sagitta Kuzin, 1950}

Collyria sagitta Kuzin, 1950: Entomologicheskoye Obozreniye 31: 274-253.

Note. Beyond the original description, nothing is known about this species. The description is too general the species to be included in the key without seeing the type material.

Distribution. Kazakhstan (Kuzin 1950).

\subsection{Collyria trichophthalma (Thomson, 1877)}

Pachymerus trichophthalmus Thomson, 1877: Opusc. Ent. Lund. 8: 732-777.

Description. Temple matt, either impunctate or with indistinct and sparse punctures. Eye surface with dense hairs. Second metasomal tergite shining, third one matt. Coloration as in $C$. coxator (Villers), but hind tibia without light base.

Distribution. Europe, Caucasus, Siberia and Sakhalin (Kolarov 1997).

\section{Key for identification of the species of Collyria}

The types of the species were not seen. The key was made on the basis of the descriptions and the key of Izquierdo \& Rey del Castillo (1985). C. fuscipennis (Kriechbaumer) and C. sagitta Kuzin are not included. 


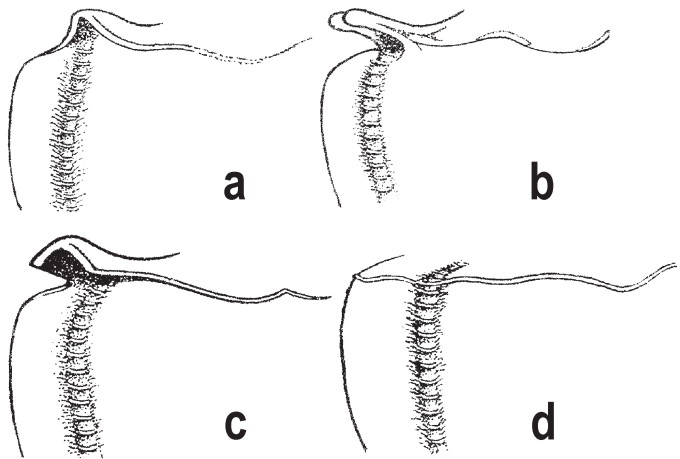

Fig. 2. Epicnemial carina from below. - a. C. coxator. - b. C. distincta. - c. C. trichophthalma. - d. C. iberica. Modified after Izquierdo \& Rey del Castillo (1985).

1. Lower tooth of mandible much longer than upper tooth; Vein 1cu-a in front wing antefurcal; gena very short

C. nigricator Aubert

- Mandibular teeth of equal size; vein $1 c u$ - $a$ interstitial; gena not as above

2. Epicnemial carina prominent from below in the middle (Fig. 2a-c)

2. Epicnemial carina not prominent from below (Fig. 2d)

3. The prominent part of epicnemial carina from below as a triangular tooth (Fig. 2a)

4

3. The prominent part of epicnemial carina from below not as a triangular tooth (Fig. $2 \mathrm{~b}-\mathrm{c}$ ) 5

4. Dorsal longitudinal carinae of propodeum parallel; face usually black

C. coxator (Villers)

4. Dorsal longitudinal carinae of propodeum divergent behind; face with yellow marks on upper eye orbits

C. orientator Aubert

5. Eyes with sparse hairs; temple matt, not punctate; epicnemial carina as in Fig. $2 \mathrm{~b}$

C. distincta Izquierdo et Rey del Castillo

5. Eyes with dense hairs; temple shining and distinctiy punctate; epicnemial carina as in Fig. 2c

C. trichophthalma (Thomson)

6. Scutellum with apical tubercle and vertical hind side (Fig. 1b); flagellum with 19 flagellomeres C. ispartasp.n.

- Scutellum without apical tubercle, rounded from behind; flagellum with 21-23 flagellomeres

C. iberica Schmiedeknecht
Acknowledgements. This work was supported by the NATO PC-B Program of TUBITAK and we would like to express our thanks for that. We are also grateful to Dr. Ilari E. Sääksjärvi and Dr. Gavin Broad for their comments on drafts and linguistic improvement of the paper.

\section{References}

Aubert, J. F.1964: Ichneumonides de France et du Bassin mediterraneen appartenant a un genre nouveau et neuf especes nouvelles. - Bull. Soc. Entomol. Mulhouse: 35-40.

Aubert, J.F. 1979: Huit Ichneumonides non petiolees inedites. - Bull. Soc. Entomol. Mulhouse: 17-22.

Filipy, F. L., Burbutis, P. P. \& Fuester, R. W. 1985: Biological control of the European wheat stem sawfly in Delaware (Hymenoptera: Cephidae). — Environmental Entomology. 14(6): 665-668.

Gauld, J. D. \& Bolton, B. 1988: The Hymenoptera. — British Museum (Natural History) and Oxford University Press, New York. 332 pp.

Geoffroy, E. L. 1785: Ichneumonidae. — In: Fourcroy, A. F. (ed.), Entomologia Parisiensis, sive catalogus insectorum quae in agro Parisiensi reperiuntur, Paris. 544 pp.

Gravenhorst, J. L. C. 1807: Vergleichende Übersicht des Linneischen und einiger Neurern Zoologischen Systeme, nebst dem eingeschalteten Verzeichnisse der Zoologischen Sammlung des Verfasser und den Beschreibungen neuer Thierarten, die in derselben vorhanden sind. Göttingen. 476 pp.

Gravenhorst, J. L. C. 1829: Ichneumonologia Europaea. Pars 3. - Vratislaviae. 1097 pp.

Izquierdo, I. M. \& C. Rey del Castillo 1985: Sobre las especies de Collyria Schiødte, 1839 (Hym., Ichneumonidae). — Eos. 60 (1984): 55-65.

Izquierdo, I. M. \& C. Rey del Castillo 1986: Descripcion de la hembra de Collyria distincta Izquierdo \& Rey del Castillo, 1985. (Hymenoptera, Ichneumonidae). Bol. Soc. Portuguesa Entomol. Supl. 1: 287-291.

Kolarov, J. 1997: Hymenoptera, Ichneumonidae, Part I. Pimplinae, Xoridinae, Acaenitinae and Collyriinae. - Fauna Bulgarica 25, Editio Academica 'Prof. Marin Drinov' \& 'Pensoft', Sofia, 320 pp. [In Bulgarian.]

Kriechbaumer, J. 1894: Beitrage zur Kenntniss der Hymenopteren-Fauna des Nördlichen China. - In: Sickmenn F. (ed.), Zoologische Jahrbücher Abteilung für Systematic 8 (1895): 197-198.

Kuzin, B. S. 1950: New species of Ichneumonids (Hymenoptera, Ichneumonidae). - Entomological Review 31: 247-253. [In Russian.]

Olivier, M. 1792: Ichneumon. — Encyclopedie methodique. Histoire naturelle. Insectes. 8: 503-518.

Salt, G. 1931: Parasites of the wheat-stem sawfly, Cephus pygmaeus in England. - Bull. Ent. Res. 22: 479-545.

Schiødte, G. 1839: Ichneumnidarum ad faunam Daniae pertinentium genera et species novae. - Magasin de Zoologie (Insect). (2)9: 1-27. 
Schmiedeknecht 1908: Opuscula Ichneumonologica. 3.Band. (Fasc. 18) Pimplinae. - Blankenburg in Thüringen. Pp.1361-1403.

Schulz, W. A. 1906: Spolia Hymenopterologica. - Paderborn (Junfermann). $356 \mathrm{pp}$.

Thomson, C. G. 1877: 27. Bidrag till kännedom om Sveriges Pimpler. - Opuscula Entomologica Lund 8: 732-777.
Yu, D. S. \&. Horstmann K. 1997: A Catalogue of world Ichneumonidae (Hymenoptera). - Memoirs of the American Entomological Institute, Vol. 58, Parts 1-2. $1558 \mathrm{pp}$.

Villers, C. de. 1789: Caroli Linnaei entomologia, Faunae Suecicae descriptionibus. Tomus tertius. - Lugduni. $657 \mathrm{pp}$. 